\title{
THE REVIEW OF RUSSIAN REGULATORY DOCUMENTS ON TAXATION ISSUES IN DECEMBER 2015 - JANUARY 2016
}

Amid financial instability, the state is not recommended to increase any form of financial pressure. On the contrary, it is advisable to limit state obligations, cut state expenditures and preserve reserves. However, the burden on taxpayers is not reduced or reduced insignificantly and only in in respect of individual groups of payers ${ }^{1}$ and sometimes it becomes even higher due to expansion of the mandatory payment base.

Administrative pressure on individuals and business across several major lines is explicitly increased:

1) new penalties and other forms of administrative responsibility for individuals and legal entities on wide-range of grounds were introduced;

2) new unpaid obligations related to the scope of duties of enforcement agencies and supervising authorities were imposed on the business;

3) application of pseud-fiscal methods in terms of imposition on market entities of obligations as regards mandatory payment at their account of costs of jobs and services which are related to the direct competence of the state and to be financed out of the state budget within the limits of collected tax revenues was expanded.

New regulatory norms implying penalties in case of a failure to comply therewith have been introduced in the Russian legislation. Amid the crisis, the need to introduce such regulations is not quite clear. Here are some examples.

1. Amendments introduced by Federal Law No.394 of 29 December 2015 to Federal Law No.125-FZ of 24 July 1998 on Mandatory Social Insurance Against Industrial Accidents and Occupational Diseases set a responsibility to carry out mandatory insurance also in respect of persons working under civil law contracts. Penalties were introduced instantly for the following violations: a failure by the insurer to provide reporting at the place of its registration, that is, a penalty in the amount of $5 \%$ of the sum of insurance contributions calculated over the past 3 months; a failure to supply documents required for control over completeness and correctness of payment of contributions, that is, a penalty in the amount of Rb200 per each document; a failure by the bank to transfer funds, that is, a penalty of up to $0.2 \%$ of the non-transferred amount per day of delay; a failure to fulfill the insurer's instructions provided that there are sufficient balances on the account, that is, a penalty of up to $0.2 \%$ per day of delay and so forth. It is noteworthy that the norm to pay insurance contributions on the amount of civil law contracts was introduced in the midst of the financial crisis - 18 years after the approval of the law in question. So, amid the crisis they expanded the mandatory payment base, that is, increased a tax burden and set penalties for a failure to comply with new requirements of the law.

1 Examples will be cited below. 
2. By Federal Law No. 408-FZ of 29 December 2015, administrative responsibility for carrying out entrepreneurial activities with violation of conditions provided for by a special permit (license) was increased 2-4-times over, in particular, from $\mathrm{Rb} 50,000$ to $\mathrm{Rb} 200,000$ for legal entities, though a self-regulating organization (SRO) was recognized as the most viable form of management.

3. By Federal Law No.391-FZ of 29 December 2015, amendments were introduced to Federal Law No.115-FZ of 7 August 2001 on Prevention of Legalization (Money Laundering) of Incomes Received by Criminal Means and Financing of Terrorism. A responsibility is established for economic entities which are of a strategic importance for the defense industry complex and the country's security and companies which are directly or indirectly controlled by them to inform the Federal Financial Monitoring Service (FFMS) or the Rosfinmonitoring on each opening, closing and modification of banking details and confirmed letters of credit with foreign banks, conclusion and termination of bank account agreements and bank deposit agreements with foreign banks and amendment thereof and purchasing and alienation of foreign banks' securities.

The information is to be provided to the FFMS within 3 business days following the day of the relevant event in an electronic format via the user account on the FFMS Web-site ${ }^{1}$. In addition to the information on opening of bank accounts and letters of credit and entering into bank deposit agreements, economic entities which are of strategic importance for the defense industry complex and security of the Russian Federation are to provide the Rosfinmonitoring with the data on agreements on maintenance of the register of security holders.

By the same law, a whole range of amendments was introduced to the Administrative Violations Code of the Russian Federation.

For an untimely provision or provision of inaccurate data on a legal entity or an individual entrepreneur to the Unified Federal Register, an administrative penalty of $\mathrm{Rb} 5000$ is charged on officials.

For a failure to provide the information on activities of legal entities if such provision is envisaged by the law, an administrative penalty of $\mathrm{Rb} 5,000$ to $\mathrm{Rb} 10,000$ is charged on officials.

For a repeated administrative violation or entry of knowingly false information on legal entities to the Unified Federal Register, an administrative penalty of $\mathrm{Rb} 10,000$ to $\mathrm{Rb} 50,000$ is charged on officials or disqualification for the period of one to three years is envisaged.

For a failure to provide or untimely provision by an economic entity which is of strategic importance for the defense industry complex of the country's security or a company which is under direct control thereof of the information required for maintaining of the register of security holders of such companies by a person having the license to carry out activities related to maintenance of the register of security holders, an administrative penalty of $\mathrm{Rb} 30,000$ to $\mathrm{Rb} 50,000$ is charged on officials or disqualification for the period of one to two years is envisaged; a penalty for legal entities may range from $\mathrm{Rb} 7000,000$ to $\mathrm{Rb} 1 \mathrm{~m}$.

As seen from the above, control on the part by state authorities over the activities of producers is simply replaced by introduction of obligations for

1 Explanations as regards the mechanism of application of regulatory norms are given in Resolution No.1479 of 29 December 2015 of the Government of the Russian Federation. 
those producers to report to supervising authorities on all the facts of their activities. For a failure to provide concrete information, a concrete penalty is set.

Actually, market operations have already determined the main competitive principles of networking between the state authorities and the business: the business is obligated to provide the required accounting statements on its activities, which statements are checked and certified by auditors and on the basis of those statements taxes are paid to the budget. All other requirements and bureaucrats' instructions which are virtually generated in the Russian Federation on a daily basis in terms of new regulatory documents obliging producers to supply various information are pseudo-forms of supplementary reporting which results in growth in costs for the business and reduce competitiveness of doing business in Russia, thus forcing business to move to territories where costs imputed by the state are much lower ${ }^{1}$.

Administrative responsibility was introduced by Federal Law No.391-FZ of 29 December 2015 in respect of individuals, including individual entrepreneurs and mangers of legal entities for a failure to submit a bankruptcy application provided that there are grounds for $\mathrm{it}^{2}$. According to the concept of the architects of the Law, introduction of administrative responsibility for hiding of the information on the state of bankruptcy is aimed at timely identification of financial insolvency of market participants by supervising authorities and reduction of the risk of engaging of funds of other market entities into inefficient schemes and deals with legal entities and individuals which are knowingly bankrupt. However, the wording establishing not only such a responsibility for insolvent parties, but also providing for a penalty to be charged for untimely submission by those parties of information to tax authorities is the height of bureaucratic invention. Functions related to timely identification of potentially insolvent parties should be carried out by auditors and tax authorities or supervising sectorial authorities as it is, for example, done in the banking sector.

An example of imposition on the payer of responsibility which is not directly related to its entrepreneurial activities, but is within the competence of law enforcement agencies and supervising authorities is collection of information on third persons, which information became known to the taxpayer in the course of business activities.

4. By Letter No. 014-12-4/11115 of 28 December 2015 of the Central Bank of Russia, it was explained that financial market entities which are entrusted by Federal Law No.173-FZ of 28 June 2014 on Information Networking Between Financial Market Entities and Authorized Agencies with a responsibility to provide information to the authored agency in case of notification of registration with foreign tax authorities, identification of foreign taxpayer-

1 It is to be reminded that by Decree No. 683 of 31 December 2015 of the President of the Russian Federation the National Security Strategy was approved. In accordance with $\mathrm{Cl} .56$ of the Strategy, the number of main threats to the national security in the economy includes low competitiveness, export-mineral pattern of development and high dependence on the foreign economic situation, lag in development and introduction of advanced technologies, national budget system imbalances, registration of ownership titles in respect of a large number of entities in foreign jurisdictions, a high share of the shadow economy, uneven development of regions and other.

2 See the explanations of 12 January 2016 of the Federal Tax Service of the RF as regards application of Federal Law No.391-FZ of 29 December 2015. 
customers, receipt of a query from foreign tax authorities to provide information on the foreign taxpayer- customer and sending of the information on foreign taxpayer-customers to foreign tax authorities are obligated to notify the Federal Tax Service to that effect from 1 January 2016 in accordance with forms placed on the Web-site of the Federal Tax Service of Russia.

Pseudo-fiscal methods - in terms of imposition of a duty on market entities to make mandatory payments for jobs and services in accordance with monopolistic tariffs - which have nothing to do with taxes. Here are some examples.

5. By Resolution No.1522 of 31 December 2015 and Resolution No.1530 of 31 December 2015, the practice of specification of the existing schemes as regards determination of wholesale prices on electricity and heat energy supply with utilization of "market" terminology, but without modification of the substance of relations (that is maintenance of high market monopolization) was continued.

The fact that the power supply market is highly monopolized can be seen from item 5 of the Wholesale Power Supply Market Rules ${ }^{1}$, under which "suppliers ...and buyers of electricity (power supply) participate in purchasing and selling of electricity and (or) power supply on the wholesale market after being granted in accordance with the adopted procedure the status of a wholesale market entity or participant in conversion of electricity and (or) power supply on the wholesale market. It is to be noted that providers and buyers enter into agreements binding on wholesale market participants and carry out other operations to supply (buy) electricity and (power supply) on the wholesale market in compliance with the Rules and agreement on joining the wholesale market trading system". All the amendments introduced by Government Resolution No.1522 of 31 December 2015, that is, specification of the location of "delivery point groups", prospects for introduction of "competitive selection of price bids a day in advance" and other are limited to a small area of activities of wholesale suppliers on the non-regulated market. The general scheme is set out in item 7 of the Rules. It can be summed up as follows: on a daily basis on the wholesale "market" in addition to competitive distribution power supply volumes not spanned by power supply capacity of generating facilities included in the list of the RF Government (that is, monopolists) are offered. Consequently, that "market" cannot influence tariffs which depend on the costs of the main generating facilities and losses related to power transmission within the frameworks of the United Energy System. Due to the above, tariffs are actually a sort of a tax charged for maintenance of the unified energy system where monopolists prevail.

6. The OAO RZhD makes money in a similar way on the "market" of monopolistic tariffs. By its Instructions No.3053u of 24 December 2015, the OAO RZhD informed counterparties that from 1 January 2016 they would index by $9 \%$ the rate of contractual fees for jobs and services envisaged by the Unified List of Jobs and Services rendered by the OAO RZhD in cargo carriage in respect of which average network rates are not set.

7. Things stand somewhat differently as regards heat energy supply. By Resolution No.1530 of 31 December 2015 of the Government of the Russian Federation, the Ministry of Energy of the Russian Federation by agreement

1 Approved by Resolution No.1172 of 27 December 2010 of the Government of the RF. 
with the Ministry of Economic Development of the Russian Federation, the Ministry of Building and Public Utilities of the Russian Federation (Minstroi of Russia) and the Federal Anti-Trust Service (FATS) of Russia is instructed to develop and submit to the Government until 1 April 2017 the draft law setting the date from which regulation of prices in agreements on supply of heat energy (power) and (or) heat carrier produced with utilization of a heat energy source with installed power capacity of below $10 \mathrm{Gcal}$ per hour and (or) the volume of supply by a heat-supply entity to heat consumer being less than $50 \mathrm{Gcal}$ for 2017 is cancelled. Due to high losses in heat transmission, for small providers mandatory conclusion of agreements on connection to the centralized heating supply system is inexpedient; autonomous heat supply systems are more efficient, so a switchover to market relations in that sector will take place at a higher rate.

In the period under review, laws regulating tax issues, including those introducing new tax privileges were approved.

8. By Federal Law No.396-FZ of 29 December 2015, the following amendments were introduced into the Tax Code of the Russian Federation. In particular, exempted from VAT payment was state and municipal property transferred free of charge to educational and scientific non-profit entities for carrying out statutory activities.

Exempted from profit tax payment was income received from sale (redemption) of shares, Russian bonds and investment units which are securities of the high-tech (innovative) sector of the economy provided that the taxpayer had an ownership title or other preparatory rights to them for over a year.

Exempted from the individual income tax payment is income from writingoff of the debt to creditors and from sale of property in case of recognition of the taxpayer as bankrupt and initiation of the procedure for sale of the debtor's property and in case of restructuring of a mortgage housing loan within the frameworks of the Russian Government aid program.

The range of persons has been expanded for whom financial assistance rendered from the federal budget and budgets of foreign states is exempted completely from the individual income tax payment and that from third persons in the amount of maximum $\mathrm{Rb} 10,000$. The list of such persons includes home front workers and POWs of the Great Patriotic War.

9. By Federal Law No. 397- $\$ 3$ of 29.12.2015, the criterion of the aggregate amount of paid taxes was reduced from $\mathrm{Rb} 10 \mathrm{bn}$ to $\mathrm{Rb} 7 \mathrm{bn}$ in the past three years (VAT, excises, corporate profit tax and the severance tax) and that permitted entity-taxpayers to apply a declarative procedure for VAT refund (the criterion does not take into account taxes withheld by a taxpayer as a tax agent).

10. By Federal Law No.401-FZ of 29 December 2015, deadlines for submitting special declarations within the frameworks of voluntary declaration of capital by individuals was extended for six months (till 30 June 2016). According to the existing legislation, such declaration does not entail a responsibility to pay any taxes or duties on declared amounts and as it pertains to those amounts a person will be relieved from criminal, administrative and tax responsibilities.

11. By Federal Law No. 406-FZ of 29 December 2015, the Budget Code of the Russian Federation was supplemented with provisions regulating the procedure for recognition of debts on payments to the budget as uncollect- 
able ones (there were the following grounds for recognition of the debt as uncollectable, in particular, as a result of death of the individual, recognition of an individual entrepreneur as bankrupt as regards debts on budget payments remaining outstanding before the budget due to insufficient property, liquidation of entity-payer and other), taking of a relevant decision and writing off of uncollectable debts in budget (book) records).

Non-tax revenues in terms of payments for provision of the data via multifunctional centers are to be paid to budgets of constituent entities of the Russian Federation in accordance with the norm of $50 \%$.

12. By Federal Law No. 398-FZ of 29 December 2015, the list of incomes of the Fund for Facilitation of Restructuring of Housing and Public Utilities, a non-profit organization which incomes were not accounted for in the composition of revenues on which a profit tax is charged and the list of that entity's expenditures which are not accounted for in determination of the tax base were specified.

Exempted from taxation were not only revenues from timely placement (investment) of funds collected for overhaul repair of an apartment house and resettlement of people from the failing housing stock, but also the income received by the Fund for modernization of utilities infrastructure (Article 251, (1), (38) of the Tax Code of the Russian Federation). Expenditures related to placement (investment) of temporary available funds collected for the above purposes were included in the composition of the Fund's expenditures which are not accounted for in determination of the profit tax base (Article 270 (48.9) of the Tax Code of the Russian Federation.

In the period under review, work continued as regards explanation by financial agencies of complex issues related to payers' mandatory payments. We find that work highly important and effective as it permits taxpayers to get promptly acquainted in accordance with the extrajudicial procedure with a substantiated position and advice of supervising authorities on a wide range of complex issues.

13. By Letter No.ED-4-2/22729 of 24 December 2015 of the Federal Tax Service of Russia, the guidelines for identification of suspicious transactions and valuation of risks of violation of the requirement of the currency legislation as regards repatriation of funds in case of replacement of nonresidents' monetary obligations by obligations in securities and set out in Letter No. 01-28/51614 of 20 October 2015 of the Federal Customs Service of Russia were sent for information and utilization in work.

Being a movable property which can be transferred through the customs border of the Eurasian Economic Union (EEU) and subjected to customs declaration, certified securities fall within the notion of "goods" and are subject to customs declaration when crossing the customs border of the EEU depending on the fact whether they are transferred by an individual as his/ her personal property or on behalf of a legal entity (that is, not for personal use).

Movement of certified securities without customs declaration can be qualified as violation of the rights of the EEU. A particular attention should be paid to transactions with bills of exchange and transformation of cash settlements into settlements with use of bills of exchange. According to the Federal Customs Service of Russia, amendment of the procedure for settlements for goods transferred to nonresidents or return to the RF of cash funds paid by 
nonresidents for goods which were not delivered to the RF by way of replacing noncash form of settlements by debt obligations in terms of a transfer by a nonresident of a bill of exchange certifying a cash claim to a resident should be regarded as a change in due dates in respect of a foreign trade deal. The Customs Service draws attention to a highly important factor: a transfer of a bill of exchange certifying a person's obligation (either a participant in the deal or a third party) as regards payment of cash funds in redemption of a bill of exchange cannot be equal to movement of foreign currency and currency of the RF in respect of a foreign trade deal. So, Russian residents are obligated within the time-limits provided for by foreign trade agreements (contracts) to secure receipt (return to the RF) from nonresidents of foreign currency or the currency of the Russian Federation in compliance with the requirements of the foreign currency legislation.

According to the Customs Service of Russia, replacement of nonresidents' monetary obligations on foreign trade deals by debt obligations (bills of exchange) can be evidence of doubtful operations and such a situation requires that parties to a foreign economic deal should comply with the foreign currency legislation.

In the Letter of the Federal Customs Service of Russia, there is a list of operations related to a transfer of securities through the customs border of the EEU and attributed to a higher risk group, for example: fulfilment of large volumes of deals with counterparties registered in offshore jurisdictions (for the amount of over $\mathrm{Rb} 30 \mathrm{~m}$ ); discounting of debt obligations; mismatch between time-limits for fulfilment of commodity obligations and those for redemption of securities and other.

14. In joint letter No.OA-4-17/22482@ of 22 December 2015 of the Ministry of Finance of the Russian Federation and the Federal Tax Service of Russia, a list of states with which the Russian Federation concluded double taxation agreements is specified. In addition to that, it is explained that due to the fact that the Russian Federation joined the Convention on Mutual Administrative Assistance in Tax Cases of 25 November 1988, from 1 January 2016 the Federal Tax Service of Russia got an opportunity to exchange the information with competent authorities of foreign states/dependent territories with which there was earlier no legal basis for such networking in the tax field (what is meant here is offshores). Undoubtedly, it is to be remembered that no automatic disclosure of the information should be expected - what is meant here is an exchange of information. The information will be provided in such volumes and formats that are not in conflict with the internal legislation and international agreements of a relevant state.

15. If positions of financial agencies are not underpinned by decisions of courts of last resort, the information regarding explanations and financial agencies' letters which are not subject to application is brought to the notice of payers by way of being placed on agencies' Web-sites and in the mass media. Such a scheme is highly technological and convenient and minimizes litigations and costs related to them. Letter No. BC-4-11/22869@ of 25 December 2015 of the Ministry of Finance of the Russian Federation and the Federal Tax Service of Russia can be sited as an example. In the above letter, the Federal Tax Service of Russia informed of the letters of the Ministry of Finance of the Russian Federation and the Federal Tax Service of Russia which were not subject to application due to approval by the Presidium of the Supreme Court 
of the Review of Consideration by Courts of Cases Related to Application of Chapter 23 of the Tax Code of the Russian Federation on 21 October 2015.

\section{It is to be noted that in the period under review the general regulatory base regulating market relations was expanded considerably.}

16. By Order No. 2776-r of 30 December 2015 of the Government of the Russian Federation, the Concept of Upgrading Mechanisms of Self-Regulation of Business and Professional Activities was approved. Development of selfregulating organization (SRO) was determined as a priority of the 2006-2010 administrative reform.

According to the Concept, as compared to direct state regulation the institute of SRO has a number of advantages, including development of the required and adequate (optimization) standards and professional business rules; introduction of the institutes of collective property responsibility for a failure to comply the standards (formation of a compensation fund); rendering of technical and consulting aid to SRO members; organization of professional monitoring and control over compliance by SRO members with the standards and rules.

Reduction of budget expenditures related to state regulation and control over compliance with standards and rules of business activities in relevant sectors of the economy was a major result of introduction of SRO.

At the same time, it is pointed out in the Concept that not all the issues were solved. At the first stage of introduction of SRO, inefficiency in fulfilment of functions related to development of sectorial standards and business rules and declarative character of approved documents are registered. There is no clear division between supervising powers of SRO and state supervising authorities. Indemnification of damage out of the compensation fund is carried out only in case of insurance event recognized either by an insurance institution or a court. SRO is not always an arbiter in disputes between its members and consumers of their goods (jobs and services). There are trends of utilizing SRO for the purpose of monopolization of markets, restraint of competition by way of establishment of barriers for entry to different sectors of the economy or introduction of horizontal limitations on the number of SRO members. Disadvantages include low efficiency of state control over activities of SRO and insufficient extent of development of legal mechanisms of their responsibility.

Within the frameworks of the Concept, efforts were taken to develop measures to upgrade efficiency of SRO operations and state agencies' supervising functions aimed at protection of consumers' interests.

17. By Federal Law No.408-FZ of 29 December 2015, criteria for recognition of economic entities and business partners as small business entities and mid-sized business entities (hereinafter SBE and MBE) ${ }^{1}$ for rendering them assistance were determined.

The above law provides for introduction of the Unified Register of SME and $\mathrm{MBE}$ for ensuring control over participation in state purchasing on the basis of Federal Law No.44-FZ of 5 April 2013 on the Contract System in Purchasing

1 Criteria for attribution to SBE and MBE of other legal entities and individual entrepreneurs, except for economic entities and business partners provided for by Federal Law No. 408-FZ of 29 December 2015 on Economic Entities and Business Partners are set by Article 4 of Federal Law No.209-FZ of 24 July 2007 on Development of Small and Mid-Sized Business in the Russian Federation. 
of Goods, Jobs and Services for Meeting State and Municipal Needs and (or) Federal Law No.223-FZ of 18 July 2011 on Purchasing of Goods, Jobs and Services by Individual Types of Legal Entities.

From 10 August 2016, the Federal Tax Service of Russia will start entering data on legal entities and individual entrepreneurs (IE) to a new unified register of small and mid-sized business entities. For that purpose, data from the Unified State Register of Legal Entities and the Unified State Register of Individual Entrepreneurs as regards the average number of workers and other data available to the Federal Tax Service of Russia as of 1 July 2016 will be used (in future for updating the register the authorized bodies will submit on the annual basis to the Federal Tax Service of Russia the required information, in particular: stock exchanges are to provide the list of joint-stock companies whose securities circulate on the organized market and attributed to high-tech sectors; state authorities carrying out legal regulation in R\&D - the list of companies engaging in implementation of innovations and outputs of intellectual activities; the Skolkovo management company - the data on participants in the Skolkovo project).

The unified register of small and mid-sized businesses placed on the official Internet site of the authorized agency will include the data on all SBE and MBE which fall within the scope both of Article 4 of Federal Law No.209-FZ of 24 July 2007 on Development of Small and Mid-Sized Business in the Russian Federation (it includes legal entities and individual entrepreneurs) and the category of economic entities and business partners attributed to SBE and MBE by Law No.408-FZ of 29 December 2015.

18. By Federal Law No.447-FZ of 30 December 2015, amendments were introduced to Federal Law No.184-FZ of 6 October 1999 on General Principles of Organization of Legislative (Representative) and Executive State Authorities of Constituent Entities of the Russian Federation and Federal Law No.131-FZ of 6 October 2003 on General Principles of Organization of Local Self-Government in the Russian Federation as regards assessment of a regulating impact of such draft statutory acts and due diligence of such regulatory statutory acts of regional and municipal levels as deal with the issues related to business and investment activities.

19. Further harmonization of activities on financial markets was carried out. By Federal Law No.407-FZ of 29 December 2015, norms regulating activities of micro-financial entities in the Russian Federation were specified. In particular, financial criteria for securing such a status - the minimum own capital of a micro-financial company is set in the amount of $\mathrm{Rb} 70 \mathrm{~m}$ (Article 5 (7) - are set. Lack of the own capital criteria with existence of the right to form reserves at the expanse of reduction of the taxable profit permitted such entities to carry out high-risk operations without financial implications for founders by way of investing the attracted (borrowed) funds in unsecured assets against high interests. The mandatory own capital criteria are aimed at upgrading the responsibility of founders for efficiency of investment of borrowed funds. A ban on a micro-financial company to act as a surety in respect of obligations of its founders, extend loans in foreign currency, grant loans if the borrower had a debt in the amount of $\mathrm{Rb} 3 \mathrm{~m}$ (in case of an individual-borrower if the debt amount exceeds $\mathrm{Rb} 500,00$ ), accrue interests to the borrower if the interest amount on loans extended for the period of a year exceeds $\mathrm{Rb} 4 \mathrm{~m}$, attract cash funds of individuals, including individual entrepreneurs (except for individuals who are founders of micro-financial 
companies), carry out production and (or) commercial activities and other contributes to that goal, too.

20. Similar amendments were introduced by Federal Law No.403 of 29 December 2015 to Federal Law on Banks and Banking and the Federal Law on Clearing and Clearing Operations. In particular, it was determined that the minimum authorized capital of a newly registered non-banking credit institution as of the day of submission of application for state registration and receipt of the license to carry out banking operations should amount minimum to $\mathrm{Rb} 90 \mathrm{~m}$, while the authorized capital of a newly registered credit institution - a central counterparty in accordance with the Federal Law on Clearing and Clearing Operations - minimum to $\mathrm{Rb} 300 \mathrm{~m}$. Mandatory norms of own capital sufficiency, aggregate resources sufficiency, individual clearing provision sufficiency, liquidation and maximum concentration risk are introduced in respect of the central counterparty. The same law set the specifics of formation, fields of competence and organization of activities of the board of directors (supervisory council) of the central counterparty. The rules of regulation of clearing activities and control thereof, as well as regulation of the central counterparty's activities and supervision thereof are specified.

In the period under review, further development of the judicial system was carried out.

21. By Federal Law No.391-FZ of 29 December 2015, amendments were introduced in a number of laws regulating legal issues related to procedures for establishment of property rights and notaries' activities as regards certification of property deals and property rights in the Russian Federation.

The above Law specifies the procedure for notarial actions in case of an application for state registration of real property by individuals, documents required for executive endorsement on the basis of the application of the claimant and administration of executive endorsement in respect of mortgage foreclosure.

By the above law, amendments were introduced to the Family Code of the $\mathrm{RF}$ as regards deals on disposal by one of the spouses of property the title to which is subject to state registration. It is established that for doing that it is necessary to receive a notary certified consent of the other spouse. Also, an agreement on division of the spouses' common property acquired in marriage is to be notary certified.

By the law in question, a norm was introduced into the Federal Law on State Registration of Titles to Real Property and Operations Therewith. Under the above norm, deals on sale of a land share are to be notary certified (Article 24.1 (3) of Federal Law No.122-FZ of 21 July 1997).

Issues related to alienation of an interest in capital are specified within the frameworks of Federal Law No.14-FZ of 8 February 1998 on Limited Liability Companies. It is established that a deal on alienation of an interest in the capital of a limited liability company can be done by way of notary certification of the agreement on acceptance of conclusion of a relevant agreement. Upon certification of the deal on alienation of the interest, a notary certifying the agreement has to submit to the authority carrying out state registration of legal entities an application for amendments regarding those legal entities to be entered in the register of legal entities. A similar procedure is provided for in respect of notary certification of the agreement on pledge of an interest or a portion of an interest in the authorized capital of the limited liability company. 
According to amendments introduced to the Arbitration Procedure Code of the Russian Federation, circumstances certified by the notary need not be proved. Also, technical corrections related to specification of functions and powers of notaries were introduced to Federal Law No.127-FZ of 26 October 2002 on Insolvency (Bankruptcy).

In addition to the above, the Law in question deals with the following issues: the specifics of recognition of developer's deals as void; the issue of a special bank account for funding construction of an uncompleted building project; the specifics of regulation of developers' obligations to participants in construction, including in case of a bankruptcy, external management, bankruptcy administration and other; the procedure for referring to the court of arbitration and documents which are to be provided to the arbitration court and the procedure for assignment of the developer's property and obligations to the buyer of that property. Also, the above law explains the procedure for referring to the arbitration court with an application to recognize an individual who is an individual entrepreneur as bankrupt.

By the Law in question, amendments were introduced to Federal Law No.115-FZ of 21 July 2015 on Concession Agreements (the list of projects which are the subject matter of concession was expanded), Federal Law No. 221-FZ of 24 July 2007 on the State Cadaster of Real Property, Federal Law No. 229-FZ of 2 October 2007 on Enforcement Proceeding, Federal Law No.173-FZ of 13 October 2008 on Additional Measures of Support to the Financial System of the Russian Federation, Federal Law No. 213-FZ of 21 July 2014 on Opening of Bank Accounts and Letters of Credit, Conclusion of Bank Deposit Agreements by Economic Entities Which Are of Strategic Importance to the Defense Industry Complex and Security of the Russian Federation and other. 